\section{参 考}

\begin{tabular}{|c|c|}
\hline \multicolumn{2}{|c|}{ 第73 回日本産業衛生学会 } \\
\hline 収入合計 & $52,720,422$ 円 \\
\hline 支出合計 & $52,720,422$ 円 \\
\hline 差引残高 & 0円 \\
\hline \multicolumn{2}{|c|}{ 第 10 回産業医・産業看護全国協議会 } \\
\hline 収入合計 & $6,902,000$ 円 \\
\hline 合計 & $6,902,000$ 円 \\
\hline 差引 & 0円 \\
\hline
\end{tabular}

\section{監查報告}

私達は, 杉本賢司公認会計士立会いのもと, 平成 12 年度経 理における理事の職務の執行を監査するため, 理事から事業の 報告を聞き，重要な収支計算書，正味財産增減計算書，貸借対 照表及び財産目録等経理関係書類を閲覧し，その他必要と思わ れる方法を用いて監査した結果，次のと抢り報告します。

1. 平成 12 年度（平成 12 年 4 月 1 日より平成 13 年 3 月 31 日） の収支決算は適正に表示しているものと認めます。

2. 理事の職務執行に関する不正の行為, または法令もしくは 定款に違反する事実の有無については，指摘すべき事実は なく, 適正かつ效率的な職務執行がなされたものと認めま $\Phi$.

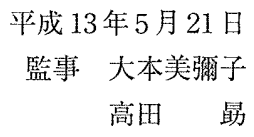

\section{平成 13 年度事業計画}

1. 評議員会を平成 13 年 4 月 4 日に, 総会を平成 13 年 4 月 6 日 に，高知市において開催する。

2. 理事会を 4 回開催する.

3. 機関誌「産業衛生学雑誌」および「J Occup Health」（第 43 巻：和文 6 册, 英文 6 冊, 学会号 1 册) を発行する.

4. 第 74 回日本産業衛生学会を平成 13 年 4 月 4 日から 8 日に わたり，高知市において，四国地方会の担当（大原啓志企 画運営委員長) で關催する。

5. 第 11 回鏟業医・産業看護全国協議会を平成 13 年 10 月 $19 \cdot 20$ 日に関東地方会・医部会・看護部会の担当（埋忠 洋一企两運営委員長) で，東京都に扔いて開催する。

6. 次の 9 地方会活動を行う.

北海道，東北，関東，北陸甲信越，東海，近畿，中国，四 国，九州の各地方会.

7. 次の部会活動を行う。
(1)産業医部会
(2)産業看護部会
(3)産業衛生技術部会

8. 次の 6 常設委員会と 1 非常設委員会の活動を行う. (1)編集委員会 (2)颜容湢度等に関する委員会 (3)生涯教育 委員会 (4)労衝衛生関連法制度検討委員会 (5)專門医制度 委員会 (6)表彰制度に基づく選考委員会 (7)産業保健活動 評価委員会 (非常設)

9. 次の 23 研究会の活動を行う。

(1)産業疲学研究会作動障害研究会

(3)職業性呼吸器疾患研究会 (4)中小企業安全衛生研究会

(5)有機溶剂中毒研究会 (6)雇業精神衛生研究会

(7)放射線原子力保健研究会 (8)腰痛研究会

(9)頸肩腕障害研究会 (10)アレルギー・免淩瑇性研究会

(11)労㗢衛生史研究会年労㗢者体力問題研究会

(13)健康教育・ヘルスプロモーション研究会

(14)生物学的モニタリング・バイオマーカー研究会

(15) VDT 作業砳究会年年) アコール問題研究会

(17)㡸業神経・行動研究会 (18)職域口腔保健研究会

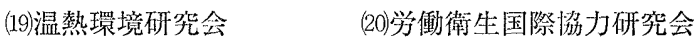

(21)産業保健情報システム研究会

(22)就労女性健康研究会

(23)化学物質取扱い淁業保健研究会

10. 日本産業衛生学会奖励賞（第 14 回），学会賞等の選考を行 い，授賞を行う。

11. 専門医制度について昨年度に引き続き指導医及び専門医の 更新及び热鬥潪資格認定試験を行うとともに，通常の指導 医認定方法である専門医からの指導医認定を行う。

12. 産業衛生に関する国際協力，とりわけアジア地域の産業保 健活動の協力を行う。

13. 定款改定作業を引き続き行う。

14. 名誉会貣の推举を行う。

15. 平成 14 年度からの役員を選出する。 